\title{
One Million Plug-in Electric Vehicles on the Road by 2015
}

\author{
Ahmed Yousuf Saber, Member, IEEE and Ganesh Kumar Venayagamoorthy, Senior Member, IEEE
}

\begin{abstract}
It is mentioned that one million plug-in hybrid and electric vehicles will be on the road by 2015 in United States to reduce emission. If one million electric vehicles (EVs) are connected to the existing electric grid randomly, peak load will be very high. Electrified transportation based on a traditional thermal power system will be costly economically and environmentally though it has a great value for electric power and transportation sectors. EVs cannot alone solve the emission problem completely since they need electric power, which is one of the main sources of emission. Therefore, significant emission reduction greatly depends on the maximum utilization of renewable energy. Two models are investigated to show the effect of one million EVs on electric power and transportation sectors. Linear and non-linear systems are used in modeling the emissions generated from the transportation and electric energy sectors respectively.
\end{abstract}

Index Terms-Emission, electric vehicles, load leveling, optimization, renewable energy, smart grid, transportation sector.

\section{INTRODUCTION}

$\mathbf{T}$ HE alarming rate, at which global energy reserves are depleting, is a major worldwide concern at economic, environmental, industrial and community levels [1]. With increasing concern over global climate change, policy makers are promoting renewable energy sources (RESs) for emissions reduction targets. A partial solution to this crisis is (a) the use of decentralized renewable energy, and (b) the widespread use of plug-in hybrid electric vehicles (PHEVs) with vehicle-togrid (V2G) capability - called "gridable vehicles". A gridable vehicle is a modified version of a plug-in hybrid electric vehicle or an electric vehicle (EV) for next generation to spark a revolution in the energy and transportation industries. For economical importance, environmental impact and social motivation, new generation vehicles (gridable vehicles) have to have capability of both charging from the grid and discharging to the grid intelligently that utilize RESs properly.

The power and energy industry is one of the most important sectors in the world since nearly every aspect of industrial productivity and daily life depends on electricity. The power and energy industry represents a major portion of global emission, which is responsible for $40 \%$ of the global $\mathrm{CO}_{2}$ production followed by the transportation sector (24\%) [2]. The estimated costs of an unabated climate change are as much as $20 \%$ of the global domestic product (GDP). However, by taking the appropriate measurements these costs could be limited to around $1 \%$ of GDP [3]. Climate change caused

This work is supported by the U.S. National Science Foundation (NSF) under NSF EFRI \# 0836017 and the CAREER Grant ECCS \# 0348221.

Authors are with the Real-Time Power and Intelligent Systems Laboratory (http://rtpis.org), Missouri University of Science and Technology, Rolla, MO 65409-0040, USA (email: aysaber@ieee.org, gkumar@ieee.org). by greenhouse gas (GHG) emissions is now widely accepted as a real condition that has potentially serious consequences for human society and industries need to factor this into their strategic plans [4]. So an environment friendly modern planning is essential.

The use of renewable energy may become attractive, especially if, customers would have to pay not only for the cost of generation but also for cost of environmental cleanup and health effects [5]. Secured power systems must have enough generation to meet demand at each moment of the day. In addition, they must also have enough reserve to deal with unexpected contingencies. Stimulated by recent technological developments and increasing concern over the sustainability and environmental impact of conventional fuel usage, the prospect of producing clean and sustainable power in substantial quantities from RESs arouses interest around the world. Energy prices, supply uncertainties, and environmental concerns are driving the United States to rethink its energy mix and develop diverse sources of clean, renewable energy. The nation is working toward generating more energy from domestic resources that can be cost-effective and replaced or renewed without contributing to climate change or major adverse environmental impacts [6].

A technical report from National Renewable Energy Laboratory (NREL) has reported that there are significant reductions in net $\mathrm{CO}_{2}$ emissions from plug-in hybrid electric vehicles (PHEVs) [7]. The combination of fluctuating high oil costs, concerns about oil security and availability, and air quality issues related to vehicle emissions are driving interest in PHEVs. The economic incentive for owners to use electricity as fuel is the comparatively low cost of fuel. Considering the cost advantage, a study by the Electric Power Research Institute (EPRI) found a significant potential market for PHEVs [8]. However, if vehicles are charged randomly, peak load will be very high and new power plants to meet this peak load needs to be installed, which is very costly. The electrification of transportation sector will need not only the re-structuring of present gasoline stations but also the modification of present power infrastructure.

The Government of United States has indicated placing one million plug-in hybrid vehicles (PHEVs) and electric vehicles (EVs) on the road by 2015 to reduce emission [9]. PHEVs and EVs cannot alone solve the emission problem completely, as they need electric power which is one of the main sources of emission. Therefore, success of practical application of PHEVs and EVs to achieve the goal of emission reduction greatly depends on the maximum utilization of renewable energy in smart grid. A smart grid should be adequate where 
there is sufficient power supply to meet the load demand with minimum cost and emission. PHEVs and EVs with additional vehicle-to-grid capability and renewable energy sources in a smart grid can help in this issue. RESs are cheap (in terms of operation cost); however, they have problems of uncertainty, reliability and stability. Technologies to dynamically optimize the time varying resources such as RESs, gridable vehicles, etc. in a complex smart grid are essential. The authors of this paper make a bridge between electric power and transportation infrastructures through gridable vehicles.

PHEV and EV researchers have mainly concentrated on the interconnection of energy storage of vehicles and grid [1016]. Their goals are to educate about the environmental and economic benefits of PHEVs and EVs, and to enhance the product market. However, power system reliability consists of system security and adequacy. Ideally, EVs should be charged from renewable sources, and gridable vehicles can act as small portable power plants (S3Ps). Besides, intelligent scheduling of S3Ps can reduce operation cost and emission.

The rest of the paper is organized as follows. In Section II, problem model is formulated for transportation and electric power sectors as linear model and non-linear model respectively. Optimization for proper utilization of sources and minimization of emissions optimization is described in Section III. Simulation data and impacts are reported and discussed in Section IV. Finally, conclusion is presented in Section V.

\section{EMISSION MODELS FOR TRANSPORTATION AND ELECTRIC POWER SECTORS}

The amount of carbon dioxide released is proportion to the amount of carbon in the fuel and the quantity of fuel burnt. Thus, a generation plant or vehicle that burns a carbonintensive fuel, generates more carbon dioxide at increased levels of operation [17]. Other types of emissions $\left(\mathrm{SO}_{2}, \mathrm{NO}_{\mathrm{X}}\right.$, etc.) are also produced from power generation systems and transportation sector.

A linear approximate model is used to calculate emission from vehicles in the transportation sector and is given as below.

$$
\mathcal{E C}_{i}\left(L_{i}, e_{i}\right)=L_{i} \times e_{i}
$$

where $\mathcal{E C}()$ is emission function, $L_{i}$ is the length of tour by vehicle $i$ in mile and $e_{i}$ is emission per mile from vehicle $i$.

However, a non-linear accurate model is used for the electric power sector. In this model, emission is expressed as a polynomial function and its order depends on desired accuracy. In this paper, a quadratic function is used for the emission calculation as given below [18].

$$
\mathcal{E C}_{i}\left(P_{i}(t)\right)=\alpha_{i}+\beta_{i} P_{i}(t)+\gamma_{i} P_{i}^{2}(t)
$$

where $\alpha_{i}, \beta_{i}$ and $\gamma_{i}$ are emission co-efficients of unit $i$.

Gridable vehicles are considered as loads or S3Ps. In the system considering GVs, power supplied from conventional units must satisfy the load demand and the system losses, which are defined in (3) and (4).

$$
\sum_{i=1}^{N} P_{i}(t)+\xi P_{v} N_{V 2 G}(t)=D(t)+\text { Losses }
$$

if $\mathrm{GVs}$ are S3Ps.

$$
\sum_{i=1}^{N} P_{i}(t)=D(t)+\xi P_{v} N_{V 2 G}(t)+\text { Losses, }
$$

if GVs are loads.

To maintain system reliability, adequate spinning reserves (5) and (6) are required.

$$
\begin{aligned}
& \sum_{i=1}^{N} P_{i}^{\max }(t)+\xi P_{v}^{\max } N_{V 2 G}(t) \geq D(t)+R(t) \\
& \text { if GVs are S3Ps. } \\
& \sum_{i=1}^{N} P_{i}^{\max }(t)+\xi P_{v}^{\max } N_{V 2 G}(t) \geq D(t)+R(t) \\
& \text { if GVs are loads. }
\end{aligned}
$$

Each unit has generation range, which is represented as

$$
P_{i}^{\min } \leq P_{i}(t) \leq P_{i}^{\max }
$$

Here $P_{i}(t)$ is power from unit $i$ at time $t ; P_{v}$ is capacity of a gridable vehicle at time $t ; N_{V 2 G}(t)$ is number of gridable vehicles connected to the grid at time $t ; \xi$ is battery efficiency; $D(t)$ is demand at time $t ; R(t)$ is spinning reserve of the system at time $t$; Losses is network losses; and so on.

\section{OPTIMIZATION OF EMISSION FROM THE Transportation AND ElEctric Power SECTORS}

A non-linear accurate model is available and used for emission calculation of power systems (2-7). However, a linear approximate (simple) model (1) is used to calculate emission from vehicles of transportation sector. An intelligent optimization method is needed to handle huge number of EVs in smart grid for proper utilization of renewable sources that reduces emission up to an optimum level. Particle swarm optimization (PSO) is used to solve this optimization problem in this paper. PSO is similar to other swarm based evolutionary algorithms [19]. Each potential solution, called a particle, flies in multi-dimensional problem space with a velocity, which is dynamically adjusted according to the flying experiences of its own and its colleagues. PSO is an intelligent iterative method where velocity (8) and position (9) of each particle are calculated as below.

$$
\begin{gathered}
v_{i j t}=w \times v_{i j t}+c_{1} \times \operatorname{rand}_{1} \times\left(\text { pbest }_{i j t}-x_{i j t}\right)+ \\
c_{2} \times \operatorname{rand}_{2} \times\left(\text { gbest }_{j t}-x_{i j t}\right) . \\
x_{i j t}=x_{i j t}+v_{i j t} .
\end{gathered}
$$

Here pbest, gbest, $v, x, w, c_{1}$, and $c_{2}$ are standard terms of PSO [19]. In the above velocity equation, the first term indicates the current velocity of the particle (inertia); second term presents the cognitive part of the particle where the particle changes its velocity based on its own thinking and memory; and the third term is the social part of PSO where the particle changes its velocity based on the social-psychological adaptation of knowledge derived from the swarm. 
TABLE I

GENERATOR EMISSION CO-EFFICIENTS

\begin{tabular}{|c|c|c|c|}
\hline Unit & $\begin{array}{c}\alpha_{i} \\
\text { ton/h) }\end{array}$ & $\begin{array}{c}\beta_{i} \\
\text { (ton/MWh) }\end{array}$ & $\begin{array}{c}\gamma_{i} \\
\text { (ton/MW }{ }^{2} \mathrm{~h} \text { ) }\end{array}$ \\
\hline U-1 & 103.3908 & -2.4444 & 0.0312 \\
U-2 & 103.3908 & -2.4444 & 0.0312 \\
U-3 & 300.3910 & -4.0695 & 0.0509 \\
U-4 & 300.3910 & -4.0695 & 0.0509 \\
U-5 & 320.0006 & -3.8132 & 0.0344 \\
U-6 & 320.0006 & -3.8132 & 0.0344 \\
U-7 & 330.0056 & -3.9023 & 0.0465 \\
U-8 & 330.0056 & -3.9023 & 0.0465 \\
U-9 & 350.0056 & -3.9524 & 0.0465 \\
U-10 & 360.0012 & -3.9864 & 0.0470 \\
\hline
\end{tabular}

TABLE II

Plant Size AND Maximum CAPACITy (1,662 MW) OF 10-Unit SYSTEM

\begin{tabular}{c|c|c|c|c|c}
\hline & Unit 1 & Unit 2 & Unit 3 & Unit 4 & Unit 5 \\
\hline$P_{i}^{\max }(\mathrm{MW})$ & 455 & 455 & 130 & 130 & 162 \\
\hline$P_{i}^{\min }(\mathrm{MW})$ & 150 & 150 & 20 & 20 & 25 \\
\hline \hline & Unit 6 & Unit 7 & Unit 8 & Unit 9 & Unit 10 \\
\hline$P_{i}^{\max }(\mathrm{MW})$ & 80 & 85 & 55 & 55 & 55 \\
\hline$P_{i}^{\min }(\mathrm{MW})$ & 20 & 25 & 10 & 10 & 10 \\
\hline
\end{tabular}

\section{RESUlts AND Discussions}

One million EVs are distributed to 20 cities where each city has $(1,000,000 / 20=) 50,000$ vehicles for simplicity of calculations. It is also more logical that all one million EVs will not be under one independent system operator (ISO) to charge (and discharge) and power system emission has non-linear characteristics for scaling. A standard ISO of 10unit system is considered for simulation with 50,000 EVs. Load demand and unit characteristics of the 10-unit system are obtained from [20]. Emission coefficients and plant data are given in Tables I and II, respectively. Two models are investigated to show the effect of one million EVs on electric power and transportation sectors.

(i) Case 1 (load leveling model): EVs charge from conventional generation using load leveling optimization;

(ii) Case 2 (smart grid model): EVs charge from renewable sources and discharge to the grid.

Parameter values are -

total number of vehicles (assumed) of a city $=50,000$; maximum battery capacity $=25 \mathrm{kWh}$; minimum battery capacity $=10 \mathrm{kWh}$; average battery capacity, $P_{v}=15 \mathrm{kWh}$; chargingdischarging frequency $=1$ per day; scheduling period $=24$ hours; departure state of charge, $\Psi=50 \%$; efficiency, $\xi=$ $85 \%$; for PSO, SwarmSize $=30$, no. of iterations $=1,000$ and accelerating parameters $c_{1}=1.5, c_{2}=2.5$.

\section{A. Load leveling model}

For practical applications, number of EVs in an electric power network can be estimated analytically based on the number of electricity clients (customers) in that network. An estimate of gridable vehicles from residential electricity clients may be computed as follows:

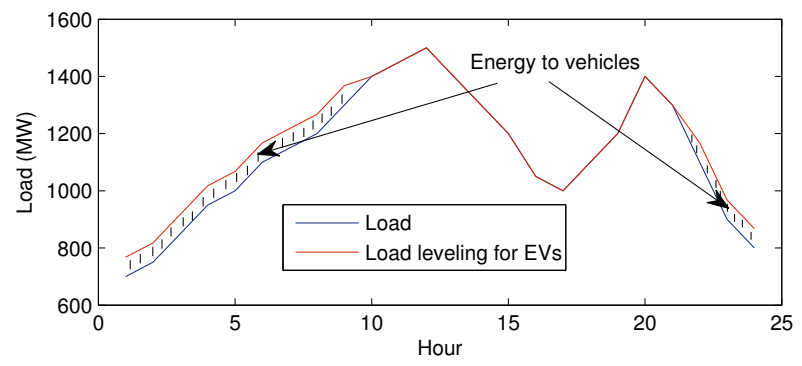

Fig. 1. Load leveling for EVs.

$$
\begin{gathered}
N_{G V}=N V_{U C-V 2 G} V_{R E C} N_{R E C} \\
=N V_{U C-V 2 G} V_{R E C} X_{R L} L_{m i n} / A V_{H L D} \\
A V_{H L D}=A V_{M E C} /(30 \times 24)
\end{gathered}
$$

where:

$$
\begin{aligned}
& N_{G V}=\text { Number of Gridable Vehicles (GVs) } \\
& N V_{U C-V 2 G}=\% \text { of the number of registered GVs for par- } \\
& \text { ticipation in "UC with V2G" } \\
& V_{R E C}=\text { Average number of gridable vehicles per res- } \\
& \text { idential electricity client } \\
& N_{R E C}=\text { Number of residential electricity clients } \\
& X_{R L} \quad=\text { Percentage of residential loads in the power } \\
& \text { network } \\
& L_{\min }=\text { Minimum load in the power network at given } \\
& \text { time (MW) } \\
& A V_{H L D}=\text { Average hourly load demand per residential } \\
& \text { electricity client }(\mathrm{kW}) \\
& A V_{M E C}=\text { Average monthly electricity consumption per } \\
& \text { residential electricity client }(\mathrm{kWh}) \text {. }
\end{aligned}
$$

For example: the minimum load, $L_{\text {min }}$, in the 10-unit benchmark system considered in this paper is $700 \mathrm{MW}$ [20]. It can be taken that the average monthly electricity consumption, $A V_{M E C}$, of a domestic home is about $1,500 \mathrm{kWh}$ [21]. Thus average hourly electricity load of a residential client, $A V_{H L D}$, is $2.0833 \mathrm{~kW}$. Assuming that $X_{R L}=30 \%$, the total number of clients in the region $N_{R E C}$, is $100,801.6$ and it can be rounded to 100,000 for simplicity. It is reasonable to assume that in the future, in United States, $V_{R E C}=1$, i.e. on average there will be one gridable vehicle per residential electricity client, and $N V_{U C-V 2 G}=50 \%$, i.e. $50 \%$ vehicles register to participant in the process. Thus, $N_{G V}$ from (10) is about 50,000 and this is a reasonable number of vehicles to be considered on the 10 -unit benchmark system for the simulation studies in this paper.

The average distance driven by a vehicle is about 12,000 miles per year [21] (32.88 miles per day). It is assumed that an EV can run 4 miles $/ \mathrm{kWh}$. Therefore an EV needs about 8.22 $\mathrm{kWh}(32.88 / 4)$ per day. Study on load forecasting including EVs are not done yet. So an approximate linear model is shown here. Total power needed for only 50,000 vehicles is $(50,000 * 8.22 \mathrm{Wh}=) 411 \mathrm{MWh}$ in a small system. If EVs are charged randomly from the existing power system, in the worst case peak load will be increased by $411 \mathrm{MW}$ which is about $25 \%$ of maximum load of the system where there are 50,000 EVs from residential customers. It is logical that 
TABLE III

EMISSION FROM 10-UNIT SYSTEM

\begin{tabular}{|c|c|c|c|c|c|c|c|c|c|c|c|c|}
\hline $\begin{array}{l}\text { Time } \\
(\mathrm{H})\end{array}$ & $\begin{array}{c}\text { U-1 } \\
\text { (MW) }\end{array}$ & $\begin{array}{c}\mathrm{U}-2 \\
\text { (MW) }\end{array}$ & $\begin{array}{c}\text { U-3 } \\
\text { (MW) }\end{array}$ & $\begin{array}{c}\mathrm{U}-4 \\
\text { (MW) }\end{array}$ & $\begin{array}{c}\text { U-5 } \\
\text { (MW) }\end{array}$ & $\begin{array}{c}\text { U-6 } \\
\text { (MW) }\end{array}$ & $\begin{array}{c}\text { U-7 } \\
\text { (MW) }\end{array}$ & $\begin{array}{c}\text { U-8 } \\
\text { (MW) }\end{array}$ & $\begin{array}{c}\text { U-9 } \\
\text { (MW) }\end{array}$ & $\begin{array}{l}\text { U-10 } \\
\text { (MW) }\end{array}$ & $\begin{array}{l}\text { Emission } \\
\text { (ton) }\end{array}$ & $\begin{array}{c}\text { Demand } \\
\text { (MW) }\end{array}$ \\
\hline H 1 & 455.0 & 244.9 & 0.0 & 0.0 & 0.0 & 0.0 & 0.0 & 0.0 & 0.0 & 0.0 & 6827.0 & 700.0 \\
\hline H 2 & 455.0 & 295.0 & 0.0 & 0.0 & 0.0 & 0.0 & 0.0 & 0.0 & 0.0 & 0.0 & 7547.2 & 750.0 \\
\hline H 3 & 455.0 & 265.0 & 0.0 & 130.0 & 0.0 & 0.0 & 0.0 & 0.0 & 0.0 & 0.0 & 7728.0 & 850.0 \\
\hline H 4 & 455.0 & 364.9 & 0.0 & 130.0 & 0.0 & 0.0 & 0.0 & 0.0 & 0.0 & 0.0 & 9448.6 & 950.0 \\
\hline H 5 & 455.0 & 285.0 & 130.0 & 130.0 & 0.0 & 0.0 & 0.0 & 0.0 & 0.0 & 0.0 & 8653.9 & 1000.0 \\
\hline H 6 & 455.0 & 385.0 & 130.0 & 130.0 & 0.0 & 0.0 & 0.0 & 0.0 & 0.0 & 0.0 & 10499.6 & 1100.0 \\
\hline H 7 & 455.0 & 410.0 & 130.0 & 130.0 & 25.0 & 0.0 & 0.0 & 0.0 & 0.0 & 0.0 & 11304.6 & 1150.0 \\
\hline H 8 & 455.0 & 455.0 & 130.0 & 130.0 & 25.0 & 0.0 & 0.0 & 0.0 & 0.0 & 0.0 & 12410.0 & 1200.0 \\
\hline H 9 & 455.0 & 455.0 & 130.0 & 130.0 & 104.9 & 0.0 & 25.0 & 0.0 & 0.0 & 0.0 & 12724.0 & 1300.0 \\
\hline H10 & 455.0 & 455.0 & 130.0 & 130.0 & 162.0 & 0.0 & 25.0 & 10.0 & 0.0 & 0.0 & 13326.1 & 1400.0 \\
\hline H1 1 & 455.0 & 455.0 & 130.0 & 130.0 & 162.0 & 0.0 & 25.0 & 55.0 & 35.1 & 0.0 & 13555.0 & 1450.0 \\
\hline H12 & 455.0 & 455.0 & 130.0 & 130.0 & 162.0 & 0.0 & 47.9 & 55.0 & 55.0 & 10.0 & 13872.9 & 1500.0 \\
\hline H13 & 455.0 & 455.0 & 130.0 & 130.0 & 162.0 & 0.0 & 25.0 & 10.0 & 0.0 & 0.0 & 13326.1 & 1400.0 \\
\hline H14 & 455.0 & 455.0 & 130.0 & 130.0 & 104.9 & 0.0 & 25.0 & 0.0 & 0.0 & 0.0 & 12724.0 & 1300.0 \\
\hline H15 & 455.0 & 455.0 & 130.0 & 130.0 & 25.0 & 0.0 & 0.0 & 0.0 & 0.0 & 0.0 & 12410.0 & 1200.0 \\
\hline H16 & 455.0 & 309.9 & 130.0 & 130.0 & 25.0 & 0.0 & 0.0 & 0.0 & 0.0 & 0.0 & 9302.4 & 1050.0 \\
\hline H17 & 455.0 & 260.0 & 130.0 & 130.0 & 25.0 & 0.0 & 0.0 & 0.0 & 0.0 & 0.0 & 8536.1 & 1000.0 \\
\hline H18 & 455.0 & 359.9 & 130.0 & 130.0 & 25.0 & 0.0 & 0.0 & 0.0 & 0.0 & 0.0 & 10225.6 & 1100.0 \\
\hline H19 & 455.0 & 455.0 & 130.0 & 130.0 & 25.0 & 0.0 & 0.0 & 0.0 & 0.0 & 0.0 & 12410.0 & 1200.0 \\
\hline $\mathrm{H} 20$ & 455.0 & 455.0 & 130.0 & 130.0 & 162.0 & 0.0 & 0.0 & 10.0 & 10.0 & 10.0 & 13704.5 & 1400.0 \\
\hline $\mathrm{H} 21$ & 455.0 & 455.0 & 130.0 & 130.0 & 119.9 & 0.0 & 0.0 & 10.0 & 0.0 & 0.0 & 12817.0 & 1300.0 \\
\hline $\mathrm{H} 22$ & 455.0 & 385.0 & 130.0 & 130.0 & 0.0 & 0.0 & 0.0 & 0.0 & 0.0 & 0.0 & 10499.6 & 1100.0 \\
\hline $\mathrm{H} 23$ & 455.0 & 315.0 & 130.0 & 0.0 & 0.0 & 0.0 & 0.0 & 0.0 & 0.0 & 0.0 & 8510.3 & 900.0 \\
\hline $\mathrm{H} 24$ & 455.0 & 345.0 & 0.0 & 0.0 & 0.0 & 0.0 & 0.0 & 0.0 & 0.0 & 0.0 & 8423.3 & 800.0 \\
\hline \multicolumn{13}{|c|}{ Total emission $=260,785.89$ tons } \\
\hline
\end{tabular}

a system may not have sufficient capacity to meet $25 \%$ extra peak load. Besides load increases by about $10 \%$ each year. In this case, it is necessary to install new generation units to meet the new load from EVs, which is costly and time consuming. However, intelligent scheduling of EVs can soften the problem by leveling the load demand intelligently. Load curve of the standard 10-unit system has both peaks and valleys (see Fig. 1 ). According to the load curve, demand is relatively low during hours from 1st to 9th and 22nd to 24th (total 12 hours). EVs can be charged from the grid during the off-peak load to level the demand. Extra $411 \mathrm{MW}$ load for 50,000 vehicles is equally distributed $(411 \mathrm{MW} / 12=34.25 \mathrm{MW}$ at each hour $)$ among the off-peak load hours to level the demand without increasing the peak load (see Fig. 1).

For the load leveling model, scheduling and controlling of EVs are very important. It is already mentioned that each day a vehicle covers an average distance of 32.88 miles and thus takes roughly less than one hour of travel time. Therefore, it can be said that on an average a vehicle is on the road less than $5 \%$ time of a day and it is parked more than $95 \%$ time of a day either in a parking lot or in a home garage. Vehicles can be charged during the $95 \%$ time of a day using an automatic intelligent agent when they are parked. It is difficult to determine whether a particular vehicle will be parked or on the road at a particular time. Thus in this model,

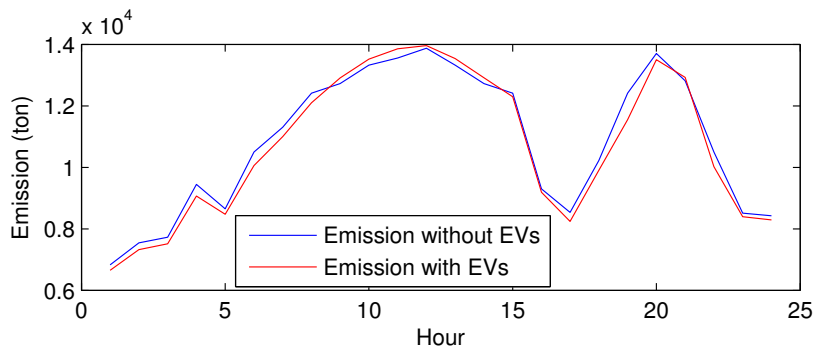

Fig. 2. Emission with and without EVs. an individual vehicle is not scheduled. However, it is possible to schedule a general number of vehicles that will be charged from the grid at every hour. It is logical that most of the vehicles are parked and depending on the schedule, committed number of vehicles (not specific vehicles) is charged using an intelligent autonomous agent, as enough number of EVs is in parking lots or in home garages. Instead of considering an individual vehicle, the aggregation of vehicles can solve the control problem of mass number of vehicles. It is essential to control some percentage of vehicles at a time and this is possible. One vehicle may leave in the middle of the operation and in this case, it will be substituted by another vehicle in a 'parking' status. Owners of the EVs will help to level the load to reduce their fuel cost. The model with EVs as a load leveling factor will be successful if real-time non-linear price rates are applied for electric power at different time of a day. Load leveling as an objective, a dynamic optimization method can be used to determine the dynamic schedule of EVs with the existing system.

An accurate model for emission from vehicles is not available. So a linear approximate model is applied to estimate the emission from vehicles. It is already mentioned that the average distance driven by a vehicle is about 12,000 miles per year. Average emission from light weight vehicles is 1.2 $\mathrm{lb} / \mathrm{mile}$. So, emission from a light weight vehicle over a year is $(12,000 * 1.2=) 144,000 \mathrm{lbs}$ and total emission from 50,000

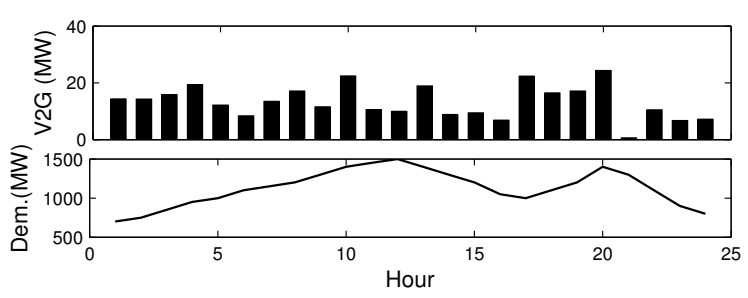

Fig. 3. Number of vehicles needed at each hour in smart grid model. 
TABLE IV

EMISSION FROM 10-UNIT SYSTEM CONSIDERING LOAD LEVELING

\begin{tabular}{|c|c|c|c|c|c|c|c|c|c|c|c|c|}
\hline $\begin{array}{l}\text { Time } \\
(\mathrm{H})\end{array}$ & $\begin{array}{c}\text { U-1 } \\
\text { (MW) }\end{array}$ & $\begin{array}{c}\mathrm{U}-2 \\
\text { (MW) }\end{array}$ & $\begin{array}{c}\mathrm{U}-3 \\
(\mathrm{MW})\end{array}$ & $\begin{array}{c}\mathrm{U}-4 \\
\text { (MW) }\end{array}$ & $\begin{array}{c}\text { U-5 } \\
\text { (MW) }\end{array}$ & $\begin{array}{c}\text { U-6 } \\
\text { (MW) }\end{array}$ & $\begin{array}{c}\text { U-7 } \\
\text { (MW) }\end{array}$ & $\begin{array}{c}\text { U-8 } \\
\text { (MW) }\end{array}$ & $\begin{array}{c}\text { U-9 } \\
\text { (MW) }\end{array}$ & $\begin{array}{l}\text { U-10 } \\
\text { (MW) }\end{array}$ & $\begin{array}{l}\text { Emission } \\
\text { (ton) }\end{array}$ & $\begin{array}{c}\text { Demand } \\
\text { (MW) }\end{array}$ \\
\hline H 1 & 455.0 & 279.2 & 0.0 & 0.0 & 0.0 & 0.0 & 0.0 & 0.0 & 0.0 & 0.0 & 7303.2 & 734.3 \\
\hline H 2 & 455.0 & 329.2 & 0.0 & 0.0 & 0.0 & 0.0 & 0.0 & 0.0 & 0.0 & 0.0 & 8130.2 & 784.3 \\
\hline H 3 & 455.0 & 299.2 & 130.0 & 0.0 & 0.0 & 0.0 & 0.0 & 0.0 & 0.0 & 0.0 & 8247.3 & 884.3 \\
\hline H 4 & 455.0 & 399.2 & 130.0 & 0.0 & 0.0 & 0.0 & 0.0 & 0.0 & 0.0 & 0.0 & 10181.7 & 984.3 \\
\hline H 5 & 455.0 & 319.2 & 130.0 & 130.0 & 0.0 & 0.0 & 0.0 & 0.0 & 0.0 & 0.0 & 9215.8 & 1034.3 \\
\hline H 6 & 455.0 & 409.3 & 130.0 & 130.0 & 0.0 & 0.0 & 0.0 & 0.0 & 0.0 & 10.0 & 11368.1 & 1134.3 \\
\hline H 7 & 455.0 & 444.2 & 130.0 & 130.0 & 25.0 & 0.0 & 0.0 & 0.0 & 0.0 & 0.0 & 12133.7 & 1184.3 \\
\hline H 8 & 455.0 & 455.0 & 130.0 & 130.0 & 64.2 & 0.0 & 0.0 & 0.0 & 0.0 & 0.0 & 12380.8 & 1234.3 \\
\hline H 9 & 455.0 & 455.0 & 130.0 & 130.0 & 119.2 & 20.0 & 25.0 & 0.0 & 0.0 & 0.0 & 13037.0 & 1334.3 \\
\hline H10 & 455.0 & 455.0 & 130.0 & 130.0 & 162.0 & 42.4 & 25.0 & 0.0 & 0.0 & 0.0 & 13250.6 & 1400.0 \\
\hline H1 1 & 455.0 & 455.0 & 130.0 & 130.0 & 162.0 & 80.0 & 25.0 & 0.0 & 10.0 & 0.0 & 13580.7 & 1450.0 \\
\hline H12 & 455.0 & 455.0 & 130.0 & 130.0 & 162.0 & 80.0 & 0.0 & 55.0 & 10.0 & 10.0 & 13900.0 & 1500.0 \\
\hline H13 & 455.0 & 455.0 & 130.0 & 130.0 & 162.0 & 47.8 & 0.0 & 10.0 & 0.0 & 10.0 & 13605.7 & 1400.0 \\
\hline H14 & 455.0 & 455.0 & 130.0 & 130.0 & 119.9 & 0.0 & 0.0 & 10.0 & 0.0 & 0.0 & 12817.0 & 1300.0 \\
\hline H15 & 455.0 & 455.0 & 130.0 & 130.0 & 25.0 & 0.0 & 0.0 & 0.0 & 0.0 & 0.0 & 12410.0 & 1200.0 \\
\hline H16 & 455.0 & 309.9 & 130.0 & 130.0 & 25.0 & 0.0 & 0.0 & 0.0 & 0.0 & 0.0 & 9302.4 & 1050.0 \\
\hline H17 & 455.0 & 260.0 & 130.0 & 130.0 & 25.0 & 0.0 & 0.0 & 0.0 & 0.0 & 0.0 & 8536.1 & 1000.0 \\
\hline H18 & 455.0 & 359.9 & 130.0 & 130.0 & 25.0 & 0.0 & 0.0 & 0.0 & 0.0 & 0.0 & 10225.6 & 1100.0 \\
\hline H19 & 455.0 & 455.0 & 130.0 & 130.0 & 25.0 & 0.0 & 0.0 & 0.0 & 0.0 & 0.0 & 12410.0 & 1200.0 \\
\hline $\mathrm{H} 20$ & 455.0 & 455.0 & 130.0 & 130.0 & 162.0 & 0.0 & 0.0 & 10.0 & 10.0 & 10.0 & 13704.5 & 1400.0 \\
\hline $\mathrm{H} 21$ & 455.0 & 455.0 & 130.0 & 130.0 & 119.9 & 0.0 & 0.0 & 10.0 & 0.0 & 0.0 & 12816.9 & 1300.0 \\
\hline $\mathrm{H} 22$ & 455.0 & 455.0 & 130.0 & 0.0 & 94.2 & 0.0 & 0.0 & 0.0 & 0.0 & 0.0 & 11798.3 & 1134.3 \\
\hline $\mathrm{H} 23$ & 455.0 & 349.2 & 130.0 & 0.0 & 0.0 & 0.0 & 0.0 & 0.0 & 0.0 & 0.0 & 9136.0 & 934.3 \\
\hline $\mathrm{H} 24$ & 455.0 & 379.2 & 0.0 & 0.0 & 0.0 & 0.0 & 0.0 & 0.0 & 0.0 & 0.0 & 9113.9 & 834.3 \\
\hline \multicolumn{13}{|c|}{ Total emission $=268,605.78$ tons } \\
\hline
\end{tabular}

vehicles is 7,200,000,000 lbs (3,266,787.66 tons).

However, a non-linear more accurate model is applied for emission from power plants. Firstly, emission is calculated for the 10-unit system with standard input data of power plants, emission co-efficients and load demand without considering EVs. PSO is used to calculate the schedule, power dispatch and corresponding emission. Results are shown in Table III. Secondly, emission is calculated considering load demand for $50,000 \mathrm{EVs}$ and leveling the extra load of vehicles (Fig. 1). These results are shown in Table IV. From Tables III and IV, excess emission is $7,819.89$ tons $(268,605.78$ tons - 260,785.89 tons) from power plants to the demand from 50,000 EVs during 24 hours. So total emission is $(7,819.89$ tons*365=) 2,854,259.85 tons per year (but 3,266,787.66 tons from transportation sector). However, network losses are not considered here. So in load leveling model, emission reduction is not guaranteed, as emission from transportation sector will be shifted to power systems. Modern technologies for mileageefficient EVs and modern emission absorption techniques for power plants can reduce emission in this model. Usually the overall efficiency of EVs $(23.1 \%)$ is higher than that of conventional vehicles (12.6\%) considering fuel energy that drives the wheels. However, emission may be increased for network losses of power systems, battery charging-discharging efficiencies, etc.

\section{B. Smart grid model}

In smart grid model, EVs can be used as loads, sources and storages. EVs can be utilized for harnessing renewable energy, storage, transportation, and providing power for both residential and commercial customers. Amount of emission reduction mainly depends on maximum utilization of renewable energy through EVs with V2G capability, where EVs can discharge as well as charge. EVs are charged from renewable sources and they discharge to the grid intelligently so that the total emission is minimal; however, load demand and constraints are fulfilled. Standard 10-unit system with 50,000 EVs are tested using PSO method to minimize the emission. Results are shown in Table V.

In Table V, emission is $257,391.18$ tons when $50,000 \mathrm{EVs}$ are considered in the 10-unit system during 24 hours. On the other hand, emission is 260,785.89 tons when EVs are not considered in the same system (Table III). Thus EVs reduce $(260,785.89$ tons $-257,391.18$ tons $=)$ 3,394.71 tons of emission per day or $1,239,069.15$ tons per year from only power plants in the 10-unit small system. Besides 50,000 EVs will replace 50,000 conventional vehicles and it is already calculated that emission is $3,266,787.66$ tons from the 50,000 light weight vehicles. So 50,000 EVs will reduce total 4,505,856.81 tons $(1,239,069.15$ tons $+3,266,787.66$ tons) emission from electric power and transportation sectors. Therefore, 20 similar cities with a total of one million EVs will reduce 90,117,136.2 tons of emissions each year.

Emission from power plants is shown in Fig. 2. PSO method is used to calculate power dispatch and corresponding emissions. Most of the time emission is lower when EVs are considered. However at peak load, emission is slightly higher because of minimum up/down time constraint, high emission rate of small plants, applied stochastic optimization method, etc.

For the one million EVs to reduce emission, wind and solar power generations are necessary in the smart grid. At least $(1,000,000 * 15 \mathrm{~kW}=) 15 \mathrm{GW}$ extra wind and solar power will be needed to get the full benefit of one million EVs for reducing emission. It will also help to achieve the target of United States to supply $10 \%$ of national electricity demand from RESs by 2012. If power generation ratio from wind and solar is $2: 1,10 \mathrm{GW}$ power will come from wind and $5 \mathrm{GW}$ from solar. Capital costs for wind and solar power are about $\$ 1 / \mathrm{W}$ and $\$ 5 / \mathrm{W}$, respectively. So capital investment in power system is at least $\left(\$ 1 * 10^{*} 10^{9}+\$ 5^{*} 5^{*} 10^{9}=\right) \$ 35$ billion to get the full advantage of one million EVs. However, it is expected 
TABLE V

SMART GRID SCHEDULE AND DISPATCH OF GENERATING UNITS AND GRIDABLE VEHICLES

\begin{tabular}{|c|c|c|c|c|c|c|c|c|c|c|c|c|c|c|}
\hline $\begin{array}{c}\text { Time } \\
(\mathrm{H})\end{array}$ & $\begin{array}{c}\mathrm{U}-1 \\
(\mathrm{MW})\end{array}$ & $\begin{array}{c}\mathrm{U}-2 \\
(\mathrm{MW})\end{array}$ & $\begin{array}{c}\mathrm{U}-3 \\
\text { (MW) }\end{array}$ & $\begin{array}{c}\mathrm{U}-4 \\
(\mathrm{MW})\end{array}$ & $\begin{array}{c}\mathrm{U}-5 \\
\text { (MW) }\end{array}$ & $\begin{array}{c}\mathrm{U}-6 \\
\text { (MW) }\end{array}$ & $\begin{array}{c}\mathrm{U}-7 \\
\text { (MW) }\end{array}$ & $\begin{array}{c}\mathrm{U}-8 \\
(\mathrm{MW})\end{array}$ & $\begin{array}{c}\text { U-9 } \\
\text { (MW) }\end{array}$ & $\begin{array}{c}\mathrm{U}-10 \\
\text { (MW) }\end{array}$ & $\begin{array}{c}\mathrm{V} 2 \mathrm{G} / \mathrm{S} 3 \mathrm{P} \\
(\mathrm{MW})\end{array}$ & $\begin{array}{c}\text { No. of } \\
\text { vehicles }\end{array}$ & $\begin{array}{l}\text { Emission } \\
\text { (ton) }\end{array}$ & $\begin{array}{c}\text { Demand } \\
\text { (MW) }\end{array}$ \\
\hline 1 & 455.0 & 230.6 & 0.0 & 0.0 & 0.0 & 0.0 & 0.0 & 0.0 & 0.0 & 0.0 & 14.37 & 2254 & 6649.2 & 700.0 \\
\hline 2 & 455.0 & 280.7 & 0.0 & 0.0 & 0.0 & 0.0 & 0.0 & 0.0 & 0.0 & 0.0 & 14.24 & 2234 & 7325.9 & 750.0 \\
\hline 3 & 455.0 & 249.1 & 0.0 & 130.0 & 0.0 & 0.0 & 0.0 & 0.0 & 0.0 & 0.0 & 15.87 & 2490 & 7512.2 & 850.0 \\
\hline 4 & 455.0 & 345.6 & 0.0 & 130.0 & 0.0 & 0.0 & 0.0 & 0.0 & 0.0 & 0.0 & 19.35 & 3035 & 9067.4 & 950.0 \\
\hline 5 & 455.0 & 272.8 & 130.0 & 130.0 & 0.0 & 0.0 & 0.0 & 0.0 & 0.0 & 0.0 & 12.17 & 1909 & 8471.6 & 1000.0 \\
\hline 6 & 455.0 & 351.6 & 130.0 & 130.0 & 25.0 & 0.0 & 0.0 & 0.0 & 0.0 & 0.0 & 8.38 & 1315 & 10060.0 & 1100.0 \\
\hline 7 & 455.0 & 396.5 & 130.0 & 130.0 & 25.0 & 0.0 & 0.0 & 0.0 & 0.0 & 0.0 & 13.50 & 2118 & 10997.8 & 1150.0 \\
\hline 8 & 455.0 & 442.8 & 130.0 & 130.0 & 25.0 & 0.0 & 0.0 & 0.0 & 0.0 & 0.0 & 17.11 & 2684 & 12099.4 & 1200.0 \\
\hline 9 & 455.0 & 455.0 & 130.0 & 130.0 & 73.4 & 20.0 & 25.0 & 0.0 & 0.0 & 0.0 & 11.55 & 1811 & 12908.3 & 1300.0 \\
\hline 10 & 455.0 & 455.0 & 130.0 & 130.0 & 152.5 & 20.0 & 25.0 & 10.0 & 0.0 & 0.0 & 22.43 & 3519 & 13517.0 & 1400.0 \\
\hline 11 & 455.0 & 455.0 & 130.0 & 130.0 & 162.0 & 62.4 & 25.0 & 10.0 & 10.0 & 0.0 & 10.53 & 1652 & 13857.2 & 1450.0 \\
\hline 12 & 455.0 & 455.0 & 130.0 & 130.0 & 162.0 & 80.0 & 25.0 & 33.0 & 10.0 & 10.0 & 9.95 & 1561 & 14157.4 & 1500.0 \\
\hline 13 & 455.0 & 455.0 & 130.0 & 130.0 & 156.0 & 20.0 & 25.0 & 10.0 & 0.0 & 0.0 & 18.89 & 2963 & 13541.1 & 1400.0 \\
\hline 14 & 455.0 & 455.0 & 130.0 & 130.0 & 76.1 & 20.0 & 25.0 & 0.0 & 0.0 & 0.0 & 8.87 & 1391 & 12911.9 & 1300.0 \\
\hline 15 & 455.0 & 450.5 & 130.0 & 130.0 & 25.0 & 0.0 & 0.0 & 0.0 & 0.0 & 0.0 & 9.42 & 1477 & 12295.0 & 1200.0 \\
\hline 16 & 455.0 & 303.1 & 130.0 & 130.0 & 25.0 & 0.0 & 0.0 & 0.0 & 0.0 & 0.0 & 6.86 & 1076 & 9188.6 & 1050.0 \\
\hline 17 & 455.0 & 237.6 & 130.0 & 130.0 & 25.0 & 0.0 & 0.0 & 0.0 & 0.0 & 0.0 & 22.33 & 3502 & 8244.1 & 1000.0 \\
\hline 18 & 455.0 & 343.5 & 130.0 & 130.0 & 25.0 & 0.0 & 0.0 & 0.0 & 0.0 & 0.0 & 16.44 & 2579 & 9904.9 & 1100.0 \\
\hline 19 & 455.0 & 397.9 & 130.0 & 130.0 & 25.0 & 20.0 & 25.0 & 0.0 & 0.0 & 0.0 & 17.15 & 2690 & 11549.0 & 1200.0 \\
\hline 20 & 455.0 & 455.0 & 130.0 & 130.0 & 150.6 & 20.0 & 25.0 & 10.0 & 0.0 & 0.0 & 24.33 & 3817 & 13504.4 & 1400.0 \\
\hline 21 & 455.0 & 455.0 & 130.0 & 130.0 & 84.3 & 20.0 & 25.0 & 0.0 & 0.0 & 0.0 & 0.63 & 99 & 12925.9 & 1300.0 \\
\hline 22 & 455.0 & 349.5 & 130.0 & 130.0 & 25.0 & 0.0 & 0.0 & 0.0 & 0.0 & 0.0 & 10.47 & 1643 & 10019.3 & 1100.0 \\
\hline 23 & 455.0 & 308.2 & 0.0 & 130.0 & 0.0 & 0.0 & 0.0 & 0.0 & 0.0 & 0.0 & 6.74 & 1057 & 8395.6 & 900.0 \\
\hline 24 & 455.0 & 337.8 & 0.0 & 0.0 & 0.0 & 0.0 & 0.0 & 0.0 & 0.0 & 0.0 & 7.17 & 1124 & 8288.1 & 800.0 \\
\hline
\end{tabular}

TABLE VI

SUMMARY OF DATA AND RESULTS

\begin{tabular}{|c|c|}
\hline Item & Value \\
\hline Mileage of a car per year & 12,000 miles/year \\
\hline Number of vehicles per city (assumed) & 50,000 \\
\hline Mileage of an EV per kWh & 4.00 miles \\
\hline Power needed for an EV per day & $8.22 \mathrm{kWh}$ \\
\hline Power needed for 50,000 EVs per day & $411 \mathrm{MWh}$ \\
\hline Typical off-peak load duration of a day & 12 hours \\
\hline Extra load for EVs per off-peak hour & $34.25 \mathrm{MW}$ \\
\hline Typical percentage of parking (controlling) time of a car & $95 \%$ \\
\hline Average emission of a light weight vehicle per mile & $1.2 \mathrm{lb} / \mathrm{mile}$ \\
\hline Average emission of a light weight vehicle over a year & $144,000 \mathrm{lbs}$ \\
\hline Emission from 50,000 vehicles (transportation sector) over a year & $3,266,787.66$ tons \\
\hline \multicolumn{2}{|l|}{ Load leveling model } \\
\hline Extra emission from power plants for 50,000 EVs during one day & $7,819.89$ tons \\
\hline Extra emission from power plants for $50,000 \mathrm{EVs}$ over a year & $2,854,259.85$ tons \\
\hline \multicolumn{2}{|l|}{$\begin{array}{ll}\text { Smart grid model } \\
\end{array}$} \\
\hline Emission reduction from power plants for 50,000 EVs $(\mathrm{V} 2 \mathrm{G})$ per day & $3,394.71$ tons \\
\hline Emission reduction from power plants for 50,000 EVs (V2G) per year & $1,239,069.15$ tons \\
\hline $\begin{array}{l}\text { Total emission reduction from power plants and transportation sector for } \\
50,000 \text { EVs (V2G) per year }\end{array}$ & $4,505,856.81$ tons \\
\hline Total emission reduction from one million EVs per year & $90,117,136.2$ tons \\
\hline \multicolumn{2}{|l|}{ Capital cost } \\
\hline Extra power needed for the smart grid model & $15 \mathrm{GW}$ \\
\hline Wind power and solar power ratio (depends on the location) & $2: 1$ \\
\hline Capital cost of wind power & $1.0 \$ / \mathrm{W}$ \\
\hline Capital cost of solar power & $5.0 \$ / \mathrm{W}$ \\
\hline Total capital investment in power system for the smart grid model & $\$ 35.0$ billion \\
\hline
\end{tabular}

to reduce per watt capital costs of solar and wind power in near future when mass amount of solar panels and wind turbines will be produced. Data and results are summarized in Table VI.

Number of vehicles connected to grid or amount of power injected to the grid is not directly proportional to the load demand. Schedule of vehicles (amount of power delivered from V2G) depends on non-linear price curves, emission curves, load demand, constraints, fitness function and balance between cost, emission. An intelligent optimization method can handle these factors efficiently. Fig. 3 shows an intelligent distribution using PSO for the system of 10-unit system and 50,000 vehicles.

Controllability is already discussed in load leveling model. The same automatic intelligent agent can be used for the smart grid model to control the charging and discharging of the gridable vehicles. 


\section{CONClusion}

A linear approximate emission model for transportation sector and a non-linear more accurate model for electric power sector have been considered in this paper for estimating the impact of one million EVs on emission reductions. Load leveling model and smart grid model are investigated. From the simulation results, emission reduction is not guaranteed in the load leveling model. On the other hand, significant amount of emission will be reduced if smart grid model is applied. However, it needs around $\$ 35$ billion of investment on renewable sources. Future work involves the use of more accurate emission model for the transportation sector and a load forecasting model with EVs using eco-traffic route data for accurate emission calculations.

\section{REFERENCES}

[1] U. K. Madawala, P. Schweizer, and V. V. Haerri, "Living and mobility- A novel multipurpose in-house grid interface with plug-in hybrid BlueAngle," IEEE International Conference on Sustainable Energy Technologies (ICSET), pp. 531-536, 24-27 Nov 2008.

[2] S. Labatt and R. R. White, "Carbon Finance: The Financial Implications of Climate Change," John Wiley \& Son, Inc., Hoboken, New Jersey, 2007.

[3] N. Stern, "The Stern Review: the Economics of Climate Change," 2006, Available: www.sternreview.org.uk.

[4] G. K. Venayagamoorthy and G. Braband, "Carbon reduction potential with intelligent control of power systems," Proc. of the 17th World Congress, The International Federation of Automatic Control, Seoul, Korea, Jul 6-11, 2008.

[5] S. Rahman and B.D. Kroposki, "Photovoltaics - An demand side management performance analysis at a university building," IEEE Trans. on Energy Conversion, vol. 8, no. 3, pp. 491-497, 1993.

[6] $20 \%$ Wind Energy by 2030: Increasing Wind Energy's Contribution to U.S. Electricity Supply, Available at http://www.eere.energy.gov/windandhydro/pdfs/41869.pdf.

[7] K. Parks, P. Denholm, and T. Markel, "Costs and emissions associated with plug-in hybrid electric vehicle charging in the Xcel Energy Colorado service territory," Technical Report NREL/TP-640-41410, May 2007.
[8] Electric Power Research Institute, "Comparing the benefits and impacts of hybrid electric vehicle options for compact sedan and sport utility vehicles," EPRI, Palo Alto, Calif., 1006891, 2002.

[9] Barack Obama and Joe Biden: New energy for America, Available: http://www.barackobama.com/pdf/factsheet_energy_speech_080308.pdf.

[10] W. Kempton, J. Tomic, S. Letendre, A. Brooks, T. Lipman, "Vehicleto-grid power: Battery, hybrid and fuel cell vehicles as resources for distributed electric power in California, Davis, CA," Institute of Transportation Studies, Report \# IUCD-ITS-RR 01-03, 2005.

[11] J. Tomic and W. Kempton, "Using fleets of electric-drive vehicles for grid support," Journal of Power Sources, vol. 168, no. 2, pp. 459-468, 1 Jun 2007.

[12] W. Kempton and J. Tomic, "Vehicle to grid fundamentals: Calculating capacity and net revenue," Journal of Power Sources, vol. 144, no. 1, pp. 268-279, 1 Jun 2005.

[13] W. Kempton and J. Tomic, "Vehicle-to-grid power implementation: From stabilizing the grid to supporting large-scale renewable energy," Journal of Power Sources, vol. 144, no. 1, pp. 280-294, 1 Jun 2005.

[14] B. D. Williams and K. S. Kurani, "Estimating the early household market for light-duty hydrogen-fuel-cell vehicles and other "Mobile Energy" innovations in California: a constraints analysis," Journal of Power Sources, vol. 160, no. 1, pp. 446-453, 29 Sep 2006.

[15] B. D. Williams and K. S. Kurani, "Commercializing light-duty plugin/plug-out hydrogen-fuel-cell vehicles: "Mobile Electricity" technologies and opportunities," Journal of Power Sources, vol. 166. no. 2, pp 549-566, 15 Apr 2007.

[16] W. Kempton and T. Kubo, "Electric-drive vehicles for peak power in Japan," Energy Policy, vol. 28, no. 1, pp. 9-18, 2000.

[17] E. Denny and M. OMalley, "Wind generation, power system operation, and emissions reduction," IEEE Trans. on Power Syst., vol. 21, no. 1, pp. 341-347, Feb 2006.

[18] P. Venkatesh, R. Gnanadass, and N. P. Padhy, "Comparison and application of evolutionary programming techniques to combined economic emission dispatch with line flow constraints," IEEE Trans. Power Syst., vol. 18, no. 2, pp. 688-697, May 2003.

[19] Y. Valle, G. K. Venayagamoorthy, S. Mohagheghi, J.-C. Hernandez, and R. G. Harley, "Particle swarm optimization: Basic concepts, variants and applications in Power Systems," IEEE Trans. Evolutionary Computation, vol. 12, no. 2, pp. 171-195, Apr 2008

[20] T. O. Ting, M. V. C. Rao, and C. K. Loo, "A novel approach for unit commitment problem via an effective hybrid particle swarm optimization," IEEE Trans. Power Syst., vol. 21, no. 1, pp. 411-418, Feb 2006.

[21] C. Roe, A.P. Meliopoulos, J. Meisel, and T. Overbye, "Power system level impacts of plug-in hybrid electric vehicles using simulation data," IEEE Energy2030, Atlanta, GA USA, 17-18 Nov 2008. 